\title{
Faktor-Faktor yang Berhubungan dengan Pemberian ASI Eksklusif Oleh Ibu Menyusui yang Bekerja Sebagai Tenaga Kesehatan
}

\author{
Hanulan Septiani ${ }^{1}$, Artha Budi ${ }^{2}$, Karbito ${ }^{3}$ \\ Program Pascasarjana Kesehatan Masyarakat Stikes Mitra Lampung ${ }^{1,2,3}$ \\ Jl. Z. A. Pagar Alam No. 7. Gedungmeneng, Bandar Lampung \\ Email: ulan.tia@gmail.com
}

\begin{abstract}
ABSTRAK
Penyebab rendahnya pemberian ASI di Indonesia adalah kurangnya pengetahuan ibu hamil, keluarga dan masyarakat akan pentingnya ASI, meningkatnya pemberian MPASI sebelum waktunya dan kurangnya dukungan dari masyarakat, termasuk institusi tempat perempuan bekerja yang belum memberikan kesempatan dan ruang khusus untuk menyusui. Penelitian ini merupakan deskriptif analitik dengan rancangan cross sectional. Populasi dalam penelitian ini adalah tenaga kesehatan perempuan di Kota Bandar Lampung yang memiliki bayi usia 724 bulan. Sampel penelitian ini diambil dari tujuh Puskesmas Kecamatan di Kota Bandar Lampung sebesar 113 responden. Data penelitian menunjukkan persentase pemberian ASI eksklusif pada tenaga kesehatan perempuan yaitu (57. 4\%). Variabel yang berhubungan dengan pemberian ASI eksklusif adalah, pengetahuan sebesar 72. 8\%, dan sikap positif sebesar 72. 1\% (faktor predisposisi). Variabel yang berhubungan dengan pemberian ASI ekslusif pada (faktor penguat) dukungan keluarga sebesar 75, 7\%, dukungan atasan 65, 9\% dan dukungan teman kerja sebesar 68, 8\%. Tidak terdapat korelasi antara ketersediaan fasilitas dan pelatihan manajemen laktasi (faktor pendorong) terhadap pemberian ASI. Faktor yang paling dominan berhubungan dengan pemberian ASI eksklusif adalah pengetahuan. Ibu dengan pengetahuan yang baik memiliki peluang untuk bisa memberikan ASI eksklusif sebesar 13 kali lebih besar dibandingkan ibu yang memiliki pengetahuan kurang.
\end{abstract}

Kata Kunci: ASI Ekslusif, Tenaga Kesehatan, Perempuan, Puskesmas

\section{FACTORS ASSOCIATED WITH EXCLUSIVE BREASTFEEDING BY WOMEN WHO WORK AS A HEALTH PERSONNEL}

\begin{abstract}
The causes of low breastfeeding in Indonesia are the lack of knowledge of pregnant women, families and communities about the importance of breastfeeding, giving weaning food (MPASI) before their time and lack of support from the community, including institutions where working women have yet to provide opportunities and special rooms for breastfeeding. This research is an analytical descriptive with cross sectional design. The population in this study is women health workers in Bandar Lampung City who have babies aged 7- 24 months. The sample of this research is taken from seven health center in Bandar Lampung city of 113 respondents. The research data shows the percentage of exclusive breastfeeding for women health workers (57. 4\%). The variables associated with exclusive breastfeeding include knowledge of $72.8 \%$, and a positive attitude of $72.1 \%$ (predisposing factors). The variables associated with exclusive breastfeeding on the family support factor (factor of strengthening) were 75, 7\%, leader support 65, 9\% and peer employee support to 68, 8\%. There is no correlation between the availability of facilities and lactation management training (pushing factors) on breastfeeding. The most dominant factor associated with exclusive breastfeeding is knowledge. Mothers with good knowledge have an opportunity to be able to give exclusive breastfeeding 13 times greater than mothers who have less knowledge.
\end{abstract}

Keywords: Exclusive Breastfeeding, Women, Health Worker, Health Centre

How to Cite: Septiani, Hanulan; Budi, Artha; Karbito. (2017). Faktor-Faktor yang Berhubungan dengan Pemberian ASI Eksklusif Oleh Ibu Menyusui yang Bekerja Sebagai Tenaga Kesehatan. Jurnal Aisyah: Jurnal Ilmu Kesehatan. 2 (2), 159 - 174. 


\section{PENDAHULUAN}

Salah satu indikator untuk mengetahui status kesehatan masyarakat di suatu negara dapat dilihat dari tingginya Angka Kematian Ibu (AKI) dan Angka Kematian Bayi (AKB). Penyebab utama kematian bayi adalah karena penyakit infeksi yaitu infeksi saluran pernafasan dan diare. Estimasi menurut Word Health Organization (WHO) bahwa 53\% kasus pneumonia akut, 55\% kematian bayi akibat diare dikarenakan pemberian makanan yang buruk pada enam bulan pertama kehidupan (Gupta, 2013).

Salah satu upaya dalam menurunkan AKB adalah dengan memberikan Air Susu Ibu (ASI) eksklusif. ASI adalah makanan alami pertama untuk bayi yang memberikan semua vitamin, mineral dan nutrisi yang diperlukan oleh bayi untuk pertumbuhan dalam enam bulan pertama dan tidak ada makanan atau cairan lain yang diperlukan. ASI memenuhi setengah atau lebih kebutuhan gizi anak pada tahun pertama hingga tahun kedua kehidupan (WHO, 2002). Disamping kandungan nutrisi yang lengkap didalam ASI juga terdapat zat kekebalan seperti $\operatorname{Ig} A, \operatorname{Ig} M, \operatorname{Ig} G, \operatorname{Ig} E$, laktoferin, lisosom, immunoglobulin dan zat lainnya yang melindungi bayi dari berbagai penyakit infeksi (Moehji, 2008). Lebih dari 136 juta bayi lahir setiap tahunnya, dan sekitar 92 juta diantaranya tidak mendapatkan ASI eksklusif sampai 6 bulan (Gupta, 2013).

Berdasarkan data Riset Kesehatan Dasar (Riskesdas, 2013) pemberian ASI eksklusif pada bayi usia $0-1$ bulan $48,7 \%$, pada usia 2-3 bulan menurun menjadi $42,2 \%$ dan semakin menurun seiring dengan meningkatnya usia bayi yaitu $36,6 \%$ pada bayi berusia $4-5$ bulan dan $30,2 \%$ pada bayi usia 6 bulan. Pada tahun 2009 pencapaian cakupan ASI eksklusif sebesar 34, $3 \%$ dan menurun pada 2010 menjadi 33, 6\% (BPS, Susenas 2010). Sedangkan Hasil Riset Kesehatan Dasar tahun 2013 jauh lebih rendah lagi yaitu 30, $2 \%$.
(Riskesdas, 2013). Angka tersebut masih jauh dari target cakupan ASI nasional yaitu sebesar $80 \%$. Bahkan berdasarkan data WBTI tahun 2012 tentang kondisi menyusui di 51 negara berdasarkan pengukuran indikator yang telah ditetapkan, Indonesia urutan ke 49 dari 51 negara dengan angka menyusui hanya sebesar 27 , $5 \%$ (IBFAN \& BPNI, 2012). Hal ini tentu sangat memprihatinkan mengingat Indonesia merupakan salah satu negara yang memiliki kebijakan tentang ASI yang cukup baik serta upaya- upaya program akselerasi untuk pencapaian ASI eksklusif yang sangat gencar baik dilakukan oleh pemerintah, swasta maupun Lembaga Swadaya Masyarakat (LSM)

Salah satu penyebab rendahnya pemberian ASI di Indonesia adalah kurangnya pengetahuan ibu hamil, keluarga dan masyarakat akan pentingnya ASI. Masalah ini diperparah dengan gencarnya promosi susu formula dan kurangnya dukungan dari masyarakat, termasuk institusi yang mempekerjakan perempuan yang belum memberikan tempat dan kesempatan bagi ibu menyusui di tempat kerja (Depkes RI, 2011).

Berbagai penelitian menunjukkan bahwa ibu yang bekerja lebih beresiko tidak memberikan ASI eksklusif dibandingkan ibu yang tidak bekerja, dimana ibu yang tidak bekerja lebih berpeluang untuk dapat memberikan ASI eksklusif sebesar 16,4 kali dibandingkan dengan ibu yang bekerja (Yuliandarin, 2009). Demikian pula dengan penelitian Kurniawan (2013) terdapat hubungan yang signifikan antara pekerjaan ibu dengan pemberian ASI eksklusif, yaitu ibu yang bekerja persentase pemberian ASI eksklusif lebih kecil dibandingkan dengan ibu yang tidak bekerja. Penelitian di Singapura terhadap 2149 ibu melahirkan di rumah sakit didapatkan hubungan yang signifikan bahwa ibu yang bekerja lebih mungkin untuk berhenti menyusui dibandingkan dengan ibu yang tidak bekerja (Ong, G; et. all, 2005). 


\section{Jurnal Aisyah: Jurnal Ilmu Kesehatan 2 (2) 2017, - 161}

Hanulan Septiani, Artha Budi, Karbito

Tenaga kesehatan perempuan merupakan bagian dari ibu bekerja yang secara fitrahnya akan menikah dan memiliki anak. Menyusui menjadi satu bagian tak terpisahkan dari proses tersebut. Keberhasilan seorang ibu dalam menyusui dipengaruhi oleh banyak faktor yaitu, faktor predisposisi, faktor pemungkin dan faktor penguat (Green 1980 dalam Notoatmojo, 2010). Faktor predisposisi yang meliputi umur, pendidikan, pengetahuan, sikap, keterpaparan terhadap informasi. Faktor pemungkin meliputi kebijakan instansi, ketersediaan fasilitas. Sedangkan faktor penguatnya adalah adanya dukungan suami, dukungan keluarga dan yang tidak kalah pentingnya adalah dukungan dari tenaga kesehatan (Abdulah, 2012). Diantara semua faktor diatas, dukungan tenaga kesehatan mempunyai nilai odds ratio (OR) paling tinggi yaitu 23,85 , artinya bahwa ibu yang mendapatkan dukungan dari tenaga kesehatan baik tenaga kesehatan penolong persalinan maupun tenaga kesehatan saat ibu kembali memeriksakan bayinya setelah pulang rawat inap dalam memfasilitasi dan mendorong ibu untuk memberikan ASI eksklusif, mempunyai peluang untuk berhasil memberikan ASI eksklusif 23,8 kali lebih besar dibandingkan dengan ibu yang tidak mendapatkan dukungan dari tenaga kesehatan (Permata, 2014). Tenaga kesehatan yang memiliki tingkat pengetahuan yang tinggi mengenai ASI eksklusif berhubungan secara signifikan terhadap dukungan pemberian ASI pada ibu menyusui (Olaolorun \& Lawoyin, 2006)

Tetapi hal ini menjadi sangat ironis, manakala tenaga kesehatan sendiri persentasenya sangat kecil yang berhasil memberikan ASI eksklusif. Dalam penelitian (Dachew\& Bifftu, 2014) yang dilakukan di Ethiopia terhadap 178 tenaga kesehatan (dokter, perawat dan bidan) didapatkan hasil hanya $35,9 \%$ yang memberikan ASI eksklusif atau sebanyak 66 tenaga kesehatan. Berdasarkan penelitian yang dilakukan di Nigeria terhadap 626 dokter hanya 11\% yang memberikan ASI eksklusif (Sadoh, 2011) sedangkan penelitian yang dilakukan di Malaysia hanya $5 \%$ perawat yang memberikan ASI eksklusif sampai 6 bulan (Sinniah, 1980 dalam Dachew, 2014). Di Indonesia penelitian yang dilakukan oleh Harjanti (2009) di sebuah RS di Semarang terhadap 35 perawat, hanya $11,4 \%$ atau 4 orang responden yang memberikan ASI eksklusif. Demikian peneltian oleh Nikmatul Khayati (2013) di sebuah RS Jawa Tengah sebagian besar manajemen laktasi tidak dilaksanakan secara optimal oleh 46 perawat $(51,1 \%)$ perawat dan sebagian yang lain 44 perawat (44\%) sudah dilakukan secara optimal. Hal ini terjadi karena pelaksanaan manajemen laktasi ini membutuhkan kerjasama yang baik dari berbagai pihak.Tanpa adanya integritasi dan kerjasama yang baik maka hal ini sulit dilaksanakan karena masalah laktasi merupakan masalah yang kompleks.

Penelitian mengenai faktor-faktor yang mempengaruhi pemberian ASI eksklusif terhadap ibu telah banyak dilakukan, tetapi sangat jarang yang meneliti pada tenaga kesehatan perempuan. Hal ini menurut peneliti menjadi sangat penting karena tenaga kesehatan mempunyai peranan penting dalam mempromosikan, mendukung pelaksanan pemberian ASI eksklusif, dimana salah satunya dipengaruhi oleh pengetahuan, pengalaman pribadi yang disebut dengan istilah experience learning (Leavitt, et all, 2009: Leviniene, et all, 2009)

Berdasarkan laporan tahunan Dinas Kesehatan Propinsi Lampung tampak bahwa cakupan pemberian Asi Ekslusif pada tahun 2011 adalah sebesar 29,24 dengan angka target $60 \%$, sedangkan pada tahun 2012 angka cakupan tercatat sebesar 30, 05\% dengan target sebesar $80 \%$ di privinsi Lampung belum mencapai target yang di tetapkan provinsi (Dinkes Provinsi Lampung, 2009) Alasan memilih Kota Bandar Lampung sebagai tempat penelitian 
karena belum memuaskan pencapaian cakupan ASI ekslusif dan juga dari tahun ke tahun menunjukkan hasil yang fluktuatif. Pada tahun 2011 tercatat pencapaian ASI ekslusif di Kota Bandar lampung sebesar $65,1 \%$ dan di tahun berikutnya 2012 terjadi peningkatan sebesar 67, 93\% namun di tahun 2013 mengalami penurunan yaitu sebesar $66,54 \%$.

Tahun 2014 cakupan pemberian ASI ekslusif di Kota Bandar Lampung adalah $68,7 \%$ terjadi peningkatan sebesar $72,9 \%$ di tahun 2015. Angka ini bila di bandingkan dengan target nasional masih dibawah dari target yang di inginkan (82, 25\%) (Dinkes Kota Bandar Lampung).

Keluarnya peraturan daerah (Perda) Provinsi Lampung No. 17 tahun 2014 tentang Pemberian ASI Ekslusif menjadi sebuah terobosan yang baik. Namun, harus diiringi dengan sosialisasi ketentuan tersebut serta pengawasan terhadap implementasinya sehingga tujuan dari keluarnya peraturan tersebut dapat di evaluasi secara berkala keberhasilannya. Upaya-upaya Pemerintah untuk Ibu Menyusui yang bekerja seiring dengan ditetapkannya PP Nomor 33 tahun 2012 tentang Pemberian Air Susu Ibu Ekslusif pada tanggal 1 Maret 2012. Peraturan ini dibuat dalam rangka melindungi, mendukung dan mempromosikan pemberian ASI Ekslusif sehingga perlu dilakukan upaya untuk meningkatkan dukungan dari Pemerintah, Pemerintah Daerah, Fasilitas Pelayanan Kesehatan dan Tenaga Kesehatan, masyarakat serta Keluarga agar ibu dapat memberikan ASI ekslusif kepada bayi. Melalui PP ini pemerintah mengharuskan pengurus tempat kerja (perusahaan, perkantoran milik pemerintah, Pemda dan swasta) serta penyelenggaraan tempat sarana umum untuk mendukung program ASI ekslusif, menyediakan fasilitas khusus untuk menyusui dan atau memerah ASI sesuai dengan kondisi kemampuan perusahaan, membuat peraturan internal yang mendukung keberhasilan program pemberian ASI ekslusif. Pengurus tempat kerja wajib memberikan kesempatan kepada ibu yang bekerja untuk memberikan ASI Ekslusif kepada bayi atau memerah ASI selama waktu kerja di tempat kerja.

Bandar Lampung merupakan wilayah yang memiliki jumlah kelahiran bayi tertinggi dibandingkan dengan wilayah lainnya, yang tentu saja dapat berpotensi tidak mendapatkan ASI eksklusif jika dukungan dari tenaga kesehatan tidak memadai, selain itu juga menjadi angka kejadian pneumonia balita tertinggi, pada tahun 2012 ditemukan 4 kasus, dan pada tahun 2013 menjadi 6 kasus. Berdasarkan jenis kelamin jumlah penderita pneumonia hampir sama antara laki-laki (51\%) dengan perempuan (49\%). (Profil Bidang Kesehatan Kota Bandar Lampung, 2013).

\section{METODOLOGI PENELITIAN}

Penelitian merupakan penelitian kuantitatif dengan menggunakan desain penelitian deskriptif analitik dengan rancangan cross sectional, yaitu penelitian yang bertujuan untuk mendeskripsikan mengenai suatu fenomena/ kejadian yang ditemukan yaitu berupa faktor resiko, efek atau hasil untuk kemudian dilakukan analisis hubungan antar variabel (Sastroasmoro dan Ismael, 2010).

Penelitian dilakukan di seluruh Puskesmas Kecamatan Kota Bandar Lampung yaitu sebanyak 20 Kecamatan. Dalam penelitian ini peneliti akan menyoroti rendahnya capaian cakupan ASI eksklusif dari sisi perilaku tenaga kesehatannya dalam memberikan ASI eksklusif.

Populasi dalam penelitian ini adalah seluruh tenaga kesehatan perempuan di Bandar Lampung yang memiliki bayi usia 7- 24 bulan. Sedangkan sampel dalam penelitian ini adalah tenaga kesehatan perempuan yang bekerja di 7 Puskesmas Kecamatan Kota Bandar Lampung dan memiliki bayi usia 7 - 24 bulan. Untuk penghitungan 
sampel dengan menggunakan rumus uji hipotesis proporsi satu populasi dengan menggunakan penghitungan sample size maka didapatkan sampel terbesar yaitu 113 responden. Dalam penelitian ini jenis data yang digunakan adalah data primer yang diperoleh langsung dari responden. Dalam pengumpulan data dilakukan dengan menggunakan kuesioner yang diisi oleh responden sendiri yang didampingi oleh peneliti maupun enumerator.

Analisa data menurut (Sugiono, 2009) adalah kegiatan mengelompokkan data berdasarkan variabel dan karakteristik responden, kemudian menyajikan data yang diteliti, melakukan pengujian dengan statistik guna menjawab rumusan dan hipotesa penelitian. Analisis dalam penelitian ini meliputi: analisa univariat, analisa bivariat dan analisa multivariate.

\section{HASIL DAN PEMBAHASAN}

\section{Analisis Univariat}

Analisis univariat adalah analisis yang bertujuan untuk mendeskripsikan atau memberikan gambaran variabel yang akan diteliti.

Tabel 1. Distribusi Responden Yang Memberikan ASI Eksklusif

\begin{tabular}{lcc}
\hline Pemberian ASI & N & Persentase \\
\hline Diberikan & 66 & 57.4 \\
Tidak diberikan & 49 & 42.6 \\
\hline Total & $\mathbf{1 1 5}$ & $\mathbf{1 0 0 . 0}$ \\
\hline
\end{tabular}

Berdasarkan tabel 1 terlihat bahwa responden yang memberikan ASI eksklusif lebih banyak yaitu sebesar (57. 4\%), dibandingkan dengan yang tidak memberikan ASI eksklusif yaitu (42.6\%).

\section{Analisis Bivariat}

Analisis bivariat digunakan untuk mengetahui ada tidaknya hubungan antara variabel independen dengan variabel dependen. Pada penelitian ini analisis bivariat dengan menggunakan uji chi square karena baik variabel dependen maupun independen berjenis kategorik.

Faktor Predisposisi, Faktor Pemungkin, dan Faktor Penguat

Pemberian ASI eksklusif lebih banyak pada kelompok umur 20-35 tahun (53. 6\%) dibandingkan pada kelompok umur $<20$ atau $>35$ tahun. Hasil analisis bivariat diperoleh nilai $p$ value $=0.194(\mathrm{p}>0.05)$, sehingga dapat disimpulkan bahwa tidak ada hubungan antara umur dengan pemberian ASI eksklusif.

Pemberian ASI eksklusif pada ibu dengan primipara lebih banyak yaitu (64\%) dibandingkan ibu dengan primipara $(52.3 \%)$. Hasil uji statistik pada analisis bivariat diperoleh nilai $p$ value $=0.255(\mathrm{p}>$ 0 . 05), sehingga dapat disimpulkan bahwa tidak ada hubungan antara paritas dengan pemberian ASI eksklusif.

Pemberian ASI eksklusif lebih banyak pada kelompok ibu dengan pengetahuan baik (72, 8\%) dibandingkan ibu dengan pengetahuan kurang (20. 6\%). Hasil uji statistik diperoleh nilai $p$ value $=0.001$, sehingga dapat disimpulkan bahwa ada hubungan yang signifikan antara pengetahuan dengan pemberian ASI eksklusif. Hasil analisis juga menunjukkan nilai OR yaitu sebesar 10,3 artinya adalah bahwa ibu dengan pengetahuan yang baik berpeluang memberikan ASI eksklusif sebesar 10, 3 kali lebih besar dibanding ibu yang memiliki pengetahuan cukup.

Pemberian ASI eksklusif lebih banyak pada kelompok responden yang memiliki sikap positif (72. 1\%) dibandingkan yang memiliki sikap negatif (40. 7\%). Hasil uji statistik diperoleh nilai $p$ value $=0.001$, sehingga dapat disimpulkan bahwa ada hubungan yang signifikan antara sikap dengan pemberian ASI eksklusif. Hasil analisis juga menunjukkan nilai OR sebesar 3.7, artinya bahwa responden yang memiliki sikap positif terhadap pemberian ASI memiliki peluang 3.7 kali lebih besar 


\section{Jurnal Aisyah: Jurnal Ilmu Kesehatan 2 (2) 2017, - 164}

Hanulan Septiani, Artha Budi, Karbito

untuk memberikan ASI eksklusif dibandingkan dengan responden yang memiliki sikap negatif terhadap ASI.

Pemberian ASI eksklusif pada kelompok yang ketersediaan fasilitasnya mendukung lebih banyak yaitu (68. 6\%) dibandingkan responden yang fasilitasnya tidak mendukung (24. 3\%). Hasil uji statistik diperoleh nilai $p$ value $=0.001(<0.05)$, sehingga dapat disimpulkan bahwa ada hubungan yang signifikan antara ketersediaan fasilitas dengan pemberian ASI eksklusif. Hasil analisis juga menunjukkan nilai OR 6.9 yang berarti bahwa ibu dengan ketersediaan fasilitas yang mendukung 6.9 kali lebih berpeluang untuk memberikan ASI dibandingkan dengan ibu yang ketersediaan fasilitasnya tidak mendukung.

Pemberian ASI eksklusif lebih banyak pada responden yang pernah mengikuti pelatihan manajemen laktasi maupun pelatihan terkait menyusui (66. 7\%) dibandingkan yang tidak pernah mengikuti pelatihan $(55.6 \%)$. Hasil uji statistik diperoleh nilai $p$ value $=0$. 731 (> 0.05), sehingga dapat disimpulkan bahwa tidak ada hubungan antara pelatihan manajemen laktasi dengan pemberian ASI eksklusif.

Pemberian ASI eksklusif lebih banyak pada responden yang mendapat dukungan dari keluarga (75. 7\%) dibandingkan yang tidak mendapat dukungan dari keluarga (28. 8\%). Hasil uji statistik diperoleh nilai $p$ value $=$ 0.001 , sehingga dapat disimpulkan bahwa ada hubungan yang signifikan antara dukungan keluarga dengan pemberian ASI eksklusif. Hasil analisis juga menunjukkan nilai OR sebesar 7, 6, artinya bahwa ibu yang mendapat dukungan keluarga memiliki peluang 7, 6 kali lebih besar untuk memberikan ASI eksklusif dibandingkan dengan ibu yang tidak mendapatkan dukungan keluarga.

Pemberian ASI eksklusif pada responden yang mendapat dukungan dari atasan lebih banyak yaitu (65. 9\%) dibandingkan yang tidak mendapatkan dukungan (36. 4\%). Hasil uji statistik diperoleh nilai $p$ value $=$ $0.006(<0.05)$, sehingga dapat disimpulkan bahwa ada hubungan antara dukungan atasan dengan pemberian ASI eksklusif

Pemberian ASI ekslusif lebih banyak pada responden yang mendapat dukungan dari teman kerja (68. 8\%) dibandingkan responden yang tidak mendapat dukungan dari teman kerja (41. 1\%). Hasil uji statistik diperoleh nilai $p$ value $=0.008$, sehingga dapat disimpulkan bahwa ada hubungan yang signifikan antara dukungan teman kerja dengan pemberian ASI eksklusif. Hasil analisis juga menunjukkan nilai OR sebesar 2. 96, artinya bahwa ibu yang mendapatkan dukungan teman kerja memiliki peluang 2.96 kali lebih besar untuk memberikan ASI eksklusif dibandingkan dengan ibu yang tidak mendapatkan dukungan dari teman kerja dalam pemberian ASI eksklusif.

\section{Analisis Multivariat}

Analisis multivariat berguna untuk mengetahui variabel/faktor yang paling dominan berhubungan dengan pemberian ASI eksklusif. Dalam melakukan analisis multivariat harus melewati beberapa tahapan yaitu seleksi bivariat, menyusun permodelan multivariat, seleksi konfounding, melakukan uji interaksi, dan menyusun permodelan akhir multivariat.

\section{Seleksi Bivariat}

Langkah pertama dalam analisis multivariat adalah masing-masing variabel independen dihubungkan dengan variabel dependennya, apabila skor $p$ value $<0,25$ maka variabel tersebut masuk kedalam tahap multivariat. Berdasarkan tabel 2 maka variabel yang ikut dalam multivariat adalah yang memiliki nilai $p$ value $<0.25$ yaitu: umur, pengetahuan, sikap, ketersediaan fasilitas, dukungan keluarga, dukungan atasan, dukungan teman kerja. 
Jurnal Aisyah: Jurnal Ilmu Kesehatan 2 (2) 2017, - 165

Hanulan Septiani, Artha Budi, Karbito

Tabel 2. Distribusi variabel dalam seleksi bivariat

\begin{tabular}{|c|c|c|}
\hline Variabel & p value & Keterangan \\
\hline Umur & 0.194 & $\begin{array}{l}\text { Kandidat } \\
\text { Multivariat }\end{array}$ \\
\hline Paritas & 0.255 & $\begin{array}{l}\text { Tidak masuk } \\
\text { multivariate }\end{array}$ \\
\hline Pelatihan Man. Laktasi & 0.731 & $\begin{array}{l}\text { Tidak masuk } \\
\text { multivariate }\end{array}$ \\
\hline Pengetahuan & 0.000 & $\begin{array}{l}\text { Kandidat } \\
\text { Multivariat }\end{array}$ \\
\hline Sikap & 0.001 & $\begin{array}{l}\text { Kandidat } \\
\text { Multivariat }\end{array}$ \\
\hline Ketersediaan Fasilitas & 0.000 & $\begin{array}{l}\text { Kandidat } \\
\text { Multivariat }\end{array}$ \\
\hline Dukungan Keluarga & 0.000 & $\begin{array}{l}\text { Kandidat } \\
\text { Multivariat }\end{array}$ \\
\hline Dukungan Atasan & 0.006 & $\begin{array}{l}\text { Kandidat } \\
\text { Multivariat }\end{array}$ \\
\hline Dukungan Teman Kerja & 0.008 & $\begin{array}{l}\text { Kandidat } \\
\text { Multivariat }\end{array}$ \\
\hline
\end{tabular}

\section{Permodelan multivariat}

Langkah selanjutnya kedelapan variabel independen dianalisis bersama-sama di tahap multivariat. Bila ada variabel dengan $p$ value $>0,05$ maka variabel dikeluarkan dari permodelan multivariat secara bertahap mulai dari $p$ value terbesar. Setelah dikeluarkan, variabel yang masih tersisa di model dilakukan evaluasi perubahan nilai OR, bila ada salah satu variabel yang nilai OR nya berubah $>10 \%$ maka variabel yang tadi dikeluarkan dapat dimasukkan kembali ke dalam permodelan. Hasil pemodelan multivariat dapat dilihat pada tabel 3.
Tabel 3. Model Pertama Multivariat

\begin{tabular}{lcc}
\hline \multicolumn{1}{c}{ Variabel } & p value & OR \\
\hline Umur & 0.637 & 1.293 \\
Pengetahuan & 0.014 & 12.252 \\
Sikap & 0.747 & 1.186 \\
Ketersediaan Fasilitas & 0.392 & 1.739 \\
Dukungan Keluarga & 0.010 & 4.036 \\
Dukungan Atasan & 0.441 & 0.599 \\
Dukungan Teman Kerja & 0.187 & 0.338 \\
\hline
\end{tabular}

Berdasarkan tabel 3. model pertama multivariat terdapat 5 variabel yang memiliki nilai $p$ value $>0,05$ yaitu variabel umur ketersediaan fasilitas, sikap, dukungan teman kerja, dukungan atasan, maka variabel-variabel tersebut dikeluarkan satu persatu dari model dimulai dari variabel dukungan atasan karena mendapatkan skor $p$ value yang terbesar.

\section{Uji Interaksi}

Langkah selanjutnya adalah melakukan uji interaksi antar variabel independen jika variabel tersebut secara substansi dinilai ada interaksi. Variabel yang diduga ada interaksi adalah pengetahuan dan sikap.

Hasil uji interaksi pada tabel 4. menunjukkan bahwa hasil uji omnibusnya sebesar 0.549 berarti $>0,05$ sehingga tidak ada interaksi antara pengetahuan dan sikap.

Tabel 4. Pemodelan Uji Interaksi

\begin{tabular}{lcccc}
\hline \multicolumn{1}{c}{ Variabel } & B & p value & OR & CI 95\% \\
\hline Pengetahuan & 2.27 & 0.042 & 9.71 & $1.0-87,0$ \\
\hline Sikap & -061 & 0.656 & 0.54 & $0.03-7.9$ \\
\hline Ketersediaan Fasilitas & 0.70 & 0.289 & 2.07 & $0.55-7.38$ \\
\hline Dukungan Keluarga & 1.42 & 0.009 & 4.14 & $1.42-12.05$ \\
\hline Dukungan Atasan & -0.54 & 0.413 & 0.58 & $0.15-2.12$ \\
\hline Dukungan Teman Kerja & -1.08 & 0.185 & 0.33 & $0.06-1.68$ \\
\hline Pengetahuan by sikap & 0.89 & 0.549 & 2.44 & $0.13-45,1$ \\
\hline
\end{tabular}

Berdasarkan model akhir multivariate pada tabel 5. dapat dijelaskan bahwa faktorfaktor yang berhubungan dengan pemberian ASI eksklusif adalah pengetahuan dan dukungan keluarga. Faktor yang paling dominan berhubungan dengan pemberian ASI eksklusif adalah pengetahuan yaitu dengan nilai OR 13 yang berarti bahwa ibu 
dengan pengetahuan baik 13 kali lebih berpeluang untuk memberikan ASI eksklusif dibandingkan dengan ibu dengan pengetahuan kurang, setelah dikontrol oleh variabel sikap, ketersediaan fasiltas, dukungan atasan dan dukungan teman kerja.

Tabel 5. Model Terakhir Multivariat

\begin{tabular}{lcccc}
\hline \multicolumn{1}{c}{ Variabel } & B & p value & OR & CI 95\% \\
\hline Pengetahuan & 2.56 & 0.012 & 13.007 & $1.8-95,2$ \\
Sikap & 0.13 & 0.793 & 1.148 & $0.4-3.2$ \\
Ketersediaan Fasilitas & 0.59 & 0.358 & 1.805 & $0.5-6.3$ \\
Dukungan Keluarga & 1.40 & 0.010 & 4.060 & $1.4-11.7$ \\
Dukungan Atasan & -0.54 & 0.406 & 0.578 & $0.1-2.1$ \\
Dukungan Teman Kerja & -1.11 & 0.173 & 0.327 & $0.0-1.6$ \\
\hline
\end{tabular}

Hasil penelitian ini memberikan gambaran persentase pemberian ASI eksklusif pada tenaga kesehatan perempuan yaitu (57.4\%). Hasil ini masih lebih baik bila dibandingkan dengan cakupan pemberian ASI berdasarkan data SDKI (2012) maupun Riskesdas (2013) yaitu sebesar 30.2 \% serta masih lebih tinggi dibandingkan cakupan di kota Banda Lampung yaitu sebesar $72,5 \%$. Namun demikian seharusnya capaian ini bisa lebih tinggi mengingat responden penelitiannya adalah tenaga kesehatan yang secara pengetahuan seharusnya lebih baik dibandingkan dengan masyarakat pada umumnya.

\section{Faktor Predisposisi terhadap pemberian ASI eksklusif}

\section{Hubungan Usia dengan Perilaku Pemberian ASI Eksklusif}

Umur merupakan variabel penting dalam siklus kehidupan manusia. Dikatakan bahwa umur terbaik untuk reproduktif sehat adalah rentang 20-35tahun. Pada usia ini dianggap sebagai periode emas untuk bereproduksi karena fungsi-fungsi organ reproduksi dinilai sudah matang sehingga siap untuk hamil, melahirkan dan menyusui. Hasil pada penelitian ini didapatkan bahwa umur terbanyak yang memberikan ASI eksklusif adalah pada rentang umur 20-35 yaitu sebanyak (74.1\%) dibandingkan dengan yang berusia $<20$ atau $>35$ tahun. Hal ini sedikit berbeda dengan penelitian Kaneko (2006) yang menyatakan bahwa proporsi menyusui terbanyak pada usia 20-39 tahun.

Hasil analisis bivariat dalam penelitian ini umur tidak berhubungan dengan perilaku pemberian ASI eksklusif, nilai $\mathrm{p}=0,194$ dimana OR sebesar 1.799 (95\% CI 0.7624.244). Hasil ini senada dengan penelitian Permata (2014) yang menyatakan bahwa tidak ada hubungan antara umur ibu dengan pemberian ASI eksklusif, hasil penelitian Abdullah (2012), juga menyatakan hal yang sama yaitu tidak ada hubungan antara umur ibu dengan pemberian ASI eksklusif. Tetapi berbeda dengan hasil penelitian yang dilakukan oleh Yulianah, dkk (2013), Rahmawati (2010) yang menyatakan bahwa terdapat hubungan bermakna antara umur ibu dengan pemberian ASI eksklusif.

\section{Hubungan Paritas Terhadap Perilaku Pemberian ASI Eksklusif}

Menurut Suraatmaja (1997) menyatakan bahwa pada kenaikan paritas, ada sedikit perubahan produksi ASI walaupun tidak bermakna. Volume ASI meningkat setelah kelahiran anak pertama dan akan menurun setelah kelahiran anak kelima. Keberhasilan pemberian ASI eksklusif dalam penelitian ini lebih banyak pada kelompok ibu dengan multipara (56.5\%) dibandingkan ibu dengan primipara. 
Hasil analisis bivariat menyatakan tidak ada hubungan antara paritas dengan pemberian ASI ekslusif. Hal ini dimungkinkan karena responden penelitian ini adalah tenaga kesehatan, sehingga pengetahuan mengenai manajemen laktasinya lebih baik, oleh karena itu baik primipara maupun multipara memiliki peluang dan kemungkinan yang sama dalam memberikan ASI eksklusif.

Hasil penelitian ini sama dengan penelitian yang dilakukan oleh Ogunlesi (2010) yang menyatakan bahwa tidak ada hubungan antara paritas dengan lama menyusui. Hal ini berbeda dengan beberapa penelitian berikut ini yang menyatakan bahwa terdapat hubungan yang signifikan antara paritas dengan pemberian ASI eksklusif yaitu : Yulianah, dkk (2013), Rahmawati (2010) menyatakan bahwa terdapat pengaruh yang signifikan antara urutan kelahiran bayi/paritas dengan pemberian ASI eksklusif, demikian juga penelitian yang dilakukan oleh (Dachew \& bifftu,2014) yang memperkuat dengan menyatakan bahwa ibu dengan multipara berpeluang 2 kali lebih mungkin untuk menyusui eksklusif dibanding dengan ibu yang primipara, serta penelitian oleh Penchlivani, et al (2005) bahwa terdapat hubungan antara paritas dengan ASI eksklusif yaitu ibu multipara menunjukkan angka lebih tinggi dalam memberikan ASI eksklusif dibandingkan dengan primipara.

Pengalaman menyusui sebelumnya juga mempengaruhi sikap ibu dalam memberikan ASI eksklusif terutama dalam menghadapi masalah-masalah saat menyusui.

\section{Hubungan Pengetahuan dengan Perilaku Pemberian ASI Eksklusif}

Pengetahuan adalah hasil penginderaan manusia, atau hasil tahu seseorang terhadap obyek melalui indera yang dimilikinya yang dipengaruhi oleh intensitas perhatian dan persepsi terhadap objek (Notoatmojo, 2010).
Pada penelitian ini $70,4 \%$ responden berpengetahuan baik. Hasil analisis bivariat menyatakan bahwa terdapat hubungan yang signifikan antara pengetahuan dengan pemberian ASI Eksklusif ( $p$ value $=0,000$ ) dengan OR 10,3 (95\% CI 3, 94 - 27, 14), sehingga dapat dijelaskan bahwa ibu dengan pengetahuan baik 10, 3 kali lebih berpeluang untuk memberikan ASI eksklusif dibandingkan dengan ibu yang berpengetahuan cukup. Hal ini sesuai dengan penelitian yang dilakukan oleh Mekuria \& Edris (2015) yang juga menyatakan bahwa terdapat hubungan yang signifikan pengetahuan dengan ASI eksklusif di mana pada ibu dengan pengetahuan yang baik berpeluang 2,6 kali lebih mungkin untuk memberikan ASI eksklusif.Demikian pula dengan penelitian yang dilakukan oleh Sriningsih (2011), Wulandari, dkk (2009) menyatakan terdapat hubungan yang signifikan antara pengetahuan tentang ASI dengan perilaku pemberian ASI eksklusif. Permata (2014) juga menyatakan bahwa ibu dengan pengetahuan tinggi tentang ASI eksklusif memiliki peluang untuk memberikan ASI eksklusif sebesar 20,8 kali dibandingkan ibu yang berpengetahuan rendah.

Hasil penelitian ini tidak sejalan dengan penelitian oleh Abdullah (2012) bahwa tingginya tingkat pengetahuan tidak selalu diiringi dengan perilaku yang positif hal ini terlihat bahwa dari ibu yang berpengetahuan baik tentang ASI eksklusif sebesar $88,3 \%$ namun yang memberikan ASI hanya $63 \%$. Hal serupa juga didapatkan dari penelitian Sadoh (2011) terhadap 36 dokter wanita di Nigeria. Hampir semua responden berpengetahuan baik tentang ASI eksklusif namun hanya $11,1 \%$ yang memberikan ASI eksklusif terhadap bayinya serta penelitian oleh Rahmawati (2010) yang menyatakan bahwa tidak ada pengaruh yang signifikan antara tingkat pengetahuan dengan pemberian ASI eksklusif. Hal ini karena perilaku seseorang selain dipengaruhi oleh faktor pengetahuan 


\section{Jurnal Aisyah: Jurnal Ilmu Kesehatan 2 (2) 2017, - 168}

Hanulan Septiani, Artha Budi, Karbito

juga di pengaruhi oleh nilai-nilai, keyakinan serta faktor pendukung lainnya.

Pada uji multivariat diketahui bahwa pengetahuan berhubungan dengan pemberian ASI eksklusif setelah dikontrol oleh variabel sikap, dukungan keluarga, dukungan atasan, dukungan teman kerja, dengan nilai $p$ value: 0.012 dan OR sebesar 13.007 (95\% CI 1.777 - 95.203). Artinya bahwa responden dengan pengetahuan baik berpeluang memberikan ASI eksklusif sebesar 13 kali dibandingkan responden dengan pengetahuan kurang.

Pengetahuan merupakan domain yang cukup penting dalam menentukan perilaku. Perilaku yang didasari pengetahuan, kesadaran dan sikap positif akan semakin langgeng. Pengetahuan yang baik akan memudahkan seseorang untuk merubah perilaku termasuk dalampraktik menyusui. Perilaku ibu untuk memberikan ASI eksklusif disebabkan oleh faktorpenyebab perilaku yang salah satunya adalahpengetahuan, dimana faktor ini menjadi dasaratau motivasi bagi individu dalam mengambil keputusan (Notoatmojo, 2002 dalam Sriningsih, 2011).

Kecenderungan tindakan pada kondisi pengetahuan yang baik adalah mendekati, menyenangi, mengharapkan obyek tertentu, sedangkan kecenderungan tindakan pada pengetahuan yang kurang adalah menjauhi, menghindari, membenci, tidak menyukai obyek tertentu (Azwar, 2011 dalam Nurhuda, dkk, 2013).

\section{Sikap Terhadap Perilaku Pemberian ASI Eksklusif}

Sikap adalah merupakan respon tertutup seseorang terhadap stimulus atau objek tertentu, yang sudah melibatkan faktor pendapat dan emosi yang bersangkutan. Salah satu teori yang dapat menjelaskan hubungan sikap dengan praktik pemberian ASI adalah teoritindakan beralasan (theory of reasoned action) oleh Ajzen dan Fishbein. Asumsi yang mendasari teoriini adalah: 1) manusia umumnya melakukan tindakan dengan cara yang masuk akal; 2) manusia akan mempertimbangkan informasi yang mendasari perhitungan akibat dari tindakan. Sikap positif tentangASI akan berpengaruh pada praktik pemberian ASI secara eksklusif. Perilaku merupakan hasil proses pengambilan keputusan yang teliti dan beralasan dengan mempertimbangkan keuntungan dan kerugian tindakan tersebut.

Hasil penelitian ini pada uji bivariat diperoleh $p$ value $=0,001$ yang berarti terdapat hubungan antara sikap dengan pemberian ASI Eksklusif, di mana sikap positif berpeluang 3,7 kali $(95 \%$ CI 1.7 8,20) untuk memberikan ASI eksklusif dibandingkan dengan responden yang memiliki sikap negatif. Hal ini sejalan dengan penelitian yang dilakukan oleh Nurhuda dan Mahmudah (2012) menunjukkan bahwa sikap ibu berhubungan dengan praktek pemberian ASI. Ibu yang menganggap bahwa ASI merupakan makanan terbaik untuk bayi berencana untuk memberikan ASI selama 6 bulan.Sikap ibu terhadap pemberian makan bayi menjadi prediktor kuat dalam pemberian ASI eksklusif. Demikian pula penelitian oleh Abdullah (2012) yang menyatakan terdapat hubungan yang signifikan sikap dengan pemberian ASI eksklusif. Semakin positif sikap seseorang semakin besar peluang untuk memberikan ASI eksklusif.

Pada uji multivariat, sikap tidak berhubungan dengan pemberian ASI Eksklusif. Penelitian ini sama dengan penelitian yang dilakukan oleh Yulianah, dkk (2013) yang menyatakan bahwa tidak ada hubungan yang signifikan sikap dengan pemberian ASI eksklusif. Pada penelitian ini meskipun saat dilakukan analisis multivariat tidak ditemukan adanya hubungan namun jika kita cermati dari hasil penelitian ini bahwa persentase ibu yang memberikan ASI eksklusif yaitu sebesar $53 \%$ memiliki sikap positif terhadap pemberian ASI eksklusif. Artinya bahwa 
sikap yang positif akan cenderung menghasilkan perilaku yang positif pula.

\section{Faktor Pemungkin terhadap Pemberian ASI eksklusif}

\section{Pelatihan Manajemen Laktasi terhadap Perilaku Pemberian ASI Eksklusif}

Pelatihan manajemen laktasi bertujuan untuk meningkatkan pengetahuan khususnya nakes dalam menyelesaikan masalah-masalah yang ditemukan saat menyusui. Dalam manajemen laktasi meliputi kegiatan Breastfeeding Technique, Breastfeeding Technology, Breastfeeding Problem Solving and Infant Issues (Manel, Martens, Walker, 2007)

Hasil analisis bivariat menunjukkan bahwa pelatihan manajemen laktasi tidak berhubungan dengan perilaku pemberian ASI eksklusif. Berdasarkan hasil kuantitatif diketahui bahwa dari 115 responden hanya $9(7.8 \%)$ yang pernah mengikuti pelatihan terkait menyusui. Meskipun pelatihan manajemen laktasi secara statistik tidak ditemukan adanya hubungan bermakna terhadap pemberian ASI eksklusif namun keikutsertaan dalam pelatihan akan membantu dalam meningkatkan pengetahuan dan ketrampilan saat menyusui.

Penelitian yang dilakukan oleh Owoaje (2002) terhadap 298 perawat dan 113 diantaranya telah mengikuti pelatihan menyusui dan hasilnya adalah terdapat hubungan yang signifikan antara pelatihan menyusui terhadap pengetahuan, sikap dan perilaku perawat dalam pemberian ASI eksklsuif. Perawat yang mendapatkan pelatihan menyusui memiliki pengetahuan yang baik dalam mengatasi masalah menyusui, serta sikap yang positif dalam mempromosikan ASI eksklsuif.

Ketersediaan Fasilitas dengan Perilaku Pemberian ASI Eksklusif

Ketersediaan fasilitas ini meliputi adanya pojok ASI, tempat penyimpan ASI perah serta peralatan yang dimiliki oleh responden dalam upaya untuk mendukung keberlangsungan dalam memberikan ASI. Hasil penelitian ini pada uji bivariat didapatkan bahwa ketersediaan fasilitas berhubungan dengan perilaku pemberian ASI eksklusif dengan nilai $p$ value 0.000 dengan OR sebesar 6.8 yang berarti bahwa ibu yang memiliki fasilitas yang mendukung akan berpeluang 6.8 kali lebih besar untuk memberikan ASI eksklusif dibandingkan dengan ibu yang ketersediaan fasilitasnya tidak mendukung. Hal ini tidak sejalan dengan penelitian Abdullah (2012) yang menyatakan bahwa ketersediaan fasilitas di instansi tidak berhubungan dengan pemberian ASI eksklusif.

Ruang laktasi/pojok ASI bukan hanya sekedar ruang untuk memerah ASI namun, lebih dari itu fungsi pojok ASI merupakan tempat di mana para ibu menyusui berkumpul dan saling bertukar pengalaman. Hal ini tentu akan memperkaya pengetahuan mengenai ASI dan laktasi. Apalagi pemerintah juga sudah membuat peraturan tentang kewajiban suatu instansi atau perusahaan untuk menyediakan fasilitas kepada karyawannya yang tertuang dalam Peraturan Menteri Kesehatan No.15 Tahun 2013 tentang tata cara penyediaan fasilitas khusus menyusui dan/atau memerah air susu ibu.

\section{Faktor Pendorong terhadap Pemberian ASI eksklusif}

\section{Dukungan Keluarga Terhadap Perilaku Pemberian ASI eksklusif}

Keluarga merupakan bagian yang sangat penting dalam kehidupan seseorang. Dukungan dari keluarga sangat diperlukan oleh seorang ibu dalam keberhasilannya memberikan ASI eksklusif, dukungan dari keluarga akan mempengaruhi keputusan ibu dalam memberikan ASI eksklusif.

Hasil uji bivariat diperoleh $p$ value $=0,000$ yang berarti bahwa dukungan keluarga berhubungan secara signifikan terhadap pemberian ASI Eksklusif, di mana ibu yang 


\section{Jurnal Aisyah: Jurnal Ilmu Kesehatan 2 (2) 2017, - 170}

Hanulan Septiani, Artha Budi, Karbito

mendapatkan dukungan dari keluarga berpeluang 7, 6 kali (95\% CI 3, 29 - 17,86) untuk memberikan ASI eksklusif dibandingkan ibu yang tidak mendapat dukungan dari keluarga. Hasil penelitianini sejalan dengan penelitian yang dilakukan oleh Umar, dkk (2013) yang menyatakan bahwa ada hubungan antaradukungan keluarga dengan pemberian ASI eksklusif, Ramadani (2009) yang menyatakan bahwa ibu yang mendapat dukungan dari suami akan berpeluang memberikan ASI eksklusif sebesar 3 kali dibandingkan ibu yang tidak mendapatkan dukungan suami, Evareny (2010) juga memperlihatkan hubungan yang signifikan antara dukungan keluarga dan peran ayah dengan perilaku pemberian ASI eksklusif di mana proporsi praktik pemberian ASI secara eksklusif padakelompok ayah yang mendukung lebih tinggi 2, 25 kali dibandingkan dengan kelompok ayah yang tidakmendukung. Permata (2014) juga menyatakan bahwa ibu yang mendapat dukungan dari keluarga memiliki peluang 14. 5 kali untuk bisa memberikan ASI eksklusif dibandingkan ibu yang tidak mendapat dukungan dari keluarga.Tetapi berbeda dengan penelitian Abdullah (2012), Rahmawati (2010), yang menyatakan bahwa tidak ada hubungan antara dukungan suami terhadap perilaku ibu dalam memberikan ASI eksklusif.

Pada uji multivariat, dukungan keluarga berhubungan dengan perilaku pemberian ASI Eksklusif $p$ value 0, 01 dan OR sebesar 4. 06 (95\% CI 7 - 11.7). Artinya bahwa responden dyang medapat dukungan keuarga berpeluang memberikan ASI eksklusif sebesar 4 kali dibandingkan responden dengan kurang mendapatkan dukungan.

Hal ini sesuai dengan penelitian yang dilakukan oleh Pisacane, et al (2005) menunjukkan bahwa ayah memainkan peran penting dalam mendukung keberhasilan menyusui dan meningkatkan angka menyusui. Data pengamatan menunjukkan bahwa ayah memiliki peran penting dalam keputusan ibu tentang cara memberi makan bayi dan ibu yang memilih untuk memberikan susu botol atau menyusui untuk waktu yang lebih singkat ketika ayah tidak mendukung.

Menurut Roesli (2005), seorang ayah dapat berperan aktif dalam keberhasilan pemberian ASI dengan jalan memberikan dukungan secara emosional dan bantuanbantuan praktis lainnya, seperti mengganti popok atau menyendawakan bayi. Hubungan yang unik antara seorang ayah dan bayinya merupakan faktor yang penting dalam pertumbuhan dan perkembangan seorang anak di kemudian hari. Ayah perlu mengerti dan memahami persoalan ASI dan menyusui agar ibu dapat menyusui dengan baik.

Keluarga, selain bisa menjadi faktor pendukung sekaligus justru bisa menjadi faktor penghambat. Keinginan ibu untuk memberikan ASI eksklusif sebaiknya sudah didiskusikan dengan keluarga terutama orang-orang yang akan tinggal bersama ibu saat bayi itu lahir misal suami, ibu, ibu mertua jauh sebelum si bayi lahir atau minimal saat fase kehamilan. Tanamkan kepada keluarga pentingnya ASI, bagaimana memberikan ASI eksklusif serta dukungan apa yang mereka bisa berikan. Hal ini menjadi penting, karena pada beberapa kasus, kegagalan seorang ibu dalam memberikan ASI eksklusif justru karena pemahaman yang salah dari keluarga, misalnya diberikan air putih supaya bayi tidak kuning, atau menambahkan bayi dengan susu formula karena bayi menangis dan beranggapan bahwa bayi masih lapar dan saat itu si ibu bayi kesulitan menolak atau menentang karena yang memberikan adalah ibu mertua maupun ibu kandungnya. Peristiwa ini akan bisa diminimalisir saat ibu maupun keluarga memiliki pengetahuan tentang ASI yang baik serta kesepakatan dan komitmen yang kuat untuk mendukung ibu dalam memberikan ASI eksklusif. 


\section{Jurnal Aisyah: Jurnal Ilmu Kesehatan 2 (2) 2017, - 171}

Hanulan Septiani, Artha Budi, Karbito

\section{Dukungan Atasan Terhadap Perilaku Pemberian ASI eksklusif}

Ibu yang bekerja memiliki resiko untuk berhenti menyusui, hal ini bisa disebabkan oleh beberapa faktor diantaranya adalah kebijakan instansi tempat ibu bekerja termasuk didalamnya kebijakan atasan yang tidak atau kurang mendukung ibu untuk tetap memberikan ASI.

Hasil analisis bivariat diperoleh nilai $\mathrm{p}=$ 0,006, OR sebesar 3.4 (95\% CI 1.4 - 7.8) yang berarti bahwa ibu yang mendpat dukungan atasan berhubungan berpeluang lebih besar untuk memberikan ASI Eksklusif. Penelitian yang dilakukan Tsai (2013) terhadap 715 ibu bekerja di perusahaan manufaktur di Taiwan, bahwa ibu yang mendapatkan beban kerja lebih rendah (tidak lebih dari 8 jam sehari) memiliki peluang tetap bisa memberikan ASI hingga 6 bulan sebesar 2,6 kali dan yang diberikan kesempatan istirahat untuk memompa ASI berpeluang 61,6 kali untuk bisa memberikan ASI eksklusif 6 bulan. Sedangkan menurut Guendelman, et al (2009) bahwa bentuk dukungan atasan yang dapat meningkatkan durasi menyusui adalah memberikan kelonggaran dalam pekerjaan maupun memberikan kesempatan untuk memerah ASI.

Hasil uji multivariate ibu yang mendapatkan dukungan tidak meingkatkan peluang untukmemberikan ASI eksklusif di mana nilai $\mathrm{p}=0,173$. Hasil penelitian ini sejalan dengan penelitian yang dilakukan oleh Abdullah (2012) yang menyatakan tidak ada hubungan yang signifikan antara dukungan pimpinan dengan perilaku pemberian ASI eksklusif. Meskipun secara statistik tidak ada hubungan, tetapi proporsi ibu yang memberikan ASI eksklusif lebih banyak pada kelompok yang mendapatkan dukungan dari atasan (71.3\%) dibandingkan ibu yang tidak mendapat dukungan dari atasan $(28.7 \%)$.

Keberhasilan ibu bekerja dalam memberikan ASI eksklusif dapat dipengaruhi oleh faktor internal yaitu niat atau komitmen ibu serta faktor ekskternal yaitu faktor yang berasal dari luar diri ibu seperti kebijakan instansi, dukungan atasan. Dukungan atasan yang baik tidak serta merta akan membuat ibu berhasil memberikan ASI eksklusif karena ada faktor yang lebih kuat yaitu bagaimana komitmen atau niat ibu, tetapi dukungan dan kebijakan instansi yang tidak mendukung pemberian ASI bisa dipastikan akan lebih besar ibu bekerja yang tidak berhasil memberikan ASI.

\section{Dukungan Teman Kerja Terhadap Perilaku Pemberian ASI eksklusif}

Dukungan teman selama di tempat kerja akan membuat ibu mempunyai kesempatan untuk tetap memberikan ASI. Ibu yang mendapat dukungan dari teman kerjanya mempunyai peluang untuk bisa memberikan ASI eksklusif sebesar 2,8 kali lebih besar dibandingkan ibu yang tidak mendapat dukungan dari teman kerjanya (Tsai, 2013).

Hasil uji bivariat pada penelitian ini didapatkan dimana nilai $p=0,008$ yang berarti bahwa di mana ibu yang mendapatkan dukungan dari teman berpeluang memberikan ASI eksklusif sebesar 2,8 kali $(95 \%$ CI 0,98 - 7,91) dibandingkan ibu yang tidak mendapatkan dukungan dari teman kerja.Penelitian ini sesuai dengan penelitian yang dilakukan oleh Tsai (2013) yang menyatakan bahwa ibu yang mendapat dukungan dari teman kerjanya mempunyai peluang untuk bisa memberikan ASI eksklusif sebesar 2.8 kali lebih besar dibandingkan ibu yang tidak mendapat dukungan dari teman kerjanya (Tsai, 2013).

Hasil Pada uji multivariat didapatkan bahwa dukungan teman tidak meningkatkan peluang ibu untuk memberikan ASI Eksklusif dengan nilai $\mathrm{p}=0,173$ dan OR sebesar 0.327 (95\% CI 0.065 - 1,634). Dari hasil analisis multivariat diatas meskipun teman kerja tidak berhubungan dengan 
pemberian ASI eksklusif setelah dikontrol oleh variabel lain, namun tidak bisa juga dikatakan bahwa dukungan teman kerja itu tidaklah penting, karena berdasarkan data bahwa persentase ibu yang menyusui ASI eksklusif berada pada kelompok yang mendapatkan dukungan dari teman kerja yaitu sebesar $55.7 \%$.

\section{KESIMPULAN DAN SARAN}

Berdasarkan hasil penelitian maka dapat ditarik kesimpulan bahwa proporsi pemberian ASI eksklusif pada tenaga kesehatan perempuan di Puskesmas Kota Bandar Lampung adalah sebesar 57,4\% cakupan. Variabel yang berhubungan dengan pemberian ASI eksklusif adalah pengetahuan sebesar $72.8 \%$, dan sikap positif sebesar $72.1 \%$ (faktor predisposisi). Variabel yang berhubungan dengan pemberian ASI ekslusif (faktor penguat) dukungan keluarga sebesar 75, 7\%, dukungan atasan $65,9 \%$ dan dukungan teman kerja sebesar $68,8 \%$. Tidak terdapat hubungan antara ketersediaan fasilitas dan pelatihan manajemen laktasi pada (faktor pendorong) terhadap pemberian ASI. Faktor yang paling dominan berhubungan dengan pemberian ASI eksklusif adalah pengetahuan. Ibu dengan pengetahuan yang baik memiliki peluang untuk bisa memberikan ASI eksklusif sebesar 13 kali lebih besar dibandingkan ibu yang memiliki pengetahuan kurang. 


\section{DAFTAR PUSTAKA}

Abdullah, G. I., Ayubi. D. (2013). Determinan Perilaku Pemberian Air Susu Ibu Eksklusif pada Ibu Pekerja. Jurnal Kesehatan Masyarakat Nasional 7 (7). 2013.

Academy of Breastfeeding Medicine. (2004). Clinical Protocol Number 8: Human Milk Storage Information for Home Use for Healthy Full Term Infants. Princeton Junction, New Jersey: Academy of Breastfeeding Medicine.

Brodribb, W., Fallon, A., Jackson, C., Hegney, D. (2008). The Relationship between Personal Breastfeeding Experience and The Breastfeeding Attitudes, Knowledge, Confidence And Effectiveness Of Australian Gp Registrars. Matern Child Nursing. 4: 264-7, 2008. [PubMed].

Badan Pusat Statistik. (2012), Tenaga kerja Indonesia naik 0, 85\%. diakses 24 February 2016 , $<$ www.ekonomi.inilah.com $>$.

Creswell, J. W. (2010). Research Design Pendekatan Kualitatif, Kuantitatif, dan Mixed. Yogyakarya: Pustaka Pelajar.

Departemen Kesehatan. (2011). Banyak Sekali Manfaat ASI Bagi Bayi dan Ibu. Depkes, 2011, diakses pada tanggal $\quad 10 \quad$ Februari 2015 (<http://www.bppsdmk.depkes.go.id/ index.php?option $=$ com content\&vie $\underline{\mathrm{w}}=$ article\&id $=170$ :banyak-sekalimanfaat-asi-bagi-bayi-danibu\&catid $=38$ :berita\&Itemid $=82>$.

Ernawati A. (2014). Pengetahuan, Komitmen, dan Dukungan Sosial dalam Pemberian ASI Eksklusif pada Pegawai Negeri Sipil. 2014, Diakses tanggal 10

Februari 2015http://litbang.patikab.go.id/inde x.php/jurnal/247.

Fikawati, S. dan Syafiq, A. (2003). Hubungan Antara Intermediate Breastfeeding dan ASI Eksklusif 4 Bulan. Jurnal Kedokteran Trisakti. Vol 22 (2), 2003.

Fikawati, S. dan Syafiq, A. (2009). Penyebab Keberhasilan dan Kegagalan Praktik Pemberian ASI Eksklusif. Jurnal Kesmas Nasional. Vol. 2 (3): 120-131, 2009.

Green. L. W; Ottoson, J. M. (2006). A Frame Work for Planning and Evaluation: PRECEEDE PROCEED Evolution and Application of The Model. $10^{e s}$ ans jornees de santé publique. Montreal, Quebec.

Gupta, A., Padhich, J. P., Suri, S. (2013). How Global Rates Of Exclusive Breastfeeding For The First 6 Months Be Enhanced. ICAN. Vol. 5 (3): 133-140, 2013.

IBFAN and BPNI. (2012). World Breastfeeding Trend Initiatives.The State of Breastfeeding in 51 Countries (Policy and Programmes). IBFAN and BPNI.

Kurniawan, B. (2013). Determinan Keberhasilan Pemberian Air Susu Ibu Eksklusif. Jurnal Kedokteran Brawijaya. Vol. 27 (4), Agustus 2013.

Khayati, N; Rachmawati, I. N; Nasution, Y. (2013). Pelaksanaan Manajemen Laktasi oleh Perawat di Rumah Sakit dan Faktor yang Mempengaruhinya. Prosiding PPNI. Jawa Tengah: PPNI, 2013. 
Jurnal Aisyah: Jurnal Ilmu Kesehatan 2 (2) 2017, - 174

Hanulan Septiani, Artha Budi, Karbito

WHO. (2014), Global Health Observatory (Gho): Situation And Trend " Infant Mortaliy". WHO, 2014 diakses 14 Februri 2016

http://www.who.int/gho/child health/mortality/neonatal infant. 